\title{
THE · ANNUAL
}

\author{
OP THE
}

\section{BRITISH SCHOOL AT ATHENS}

No. XIV.

SESSION $1907-1908$

PRINTED FOR THE SUBSCRIBERS AND SOLD ON THEIR BEHALF BY MACMILLAN \& CO., LimTtEV LONDON 


\section{THE ANNUAL}

"

\section{BRITISH SCHOOL AT ATHENS}

No, XIV.

SESSION 1907-1908

PRINTED FOR THE SUBSCRIBERS AND SOLD ON THEIR BEHALF BY

MACMILLAN \& CO., LIMITED

LONDON 


\title{
THE BRITISH SCHOOL AT ATHENS
}

\author{
PATRON.-HIS MAJESTY THE KING.
}

MANAGING COMMITTEE, 1907-I908.

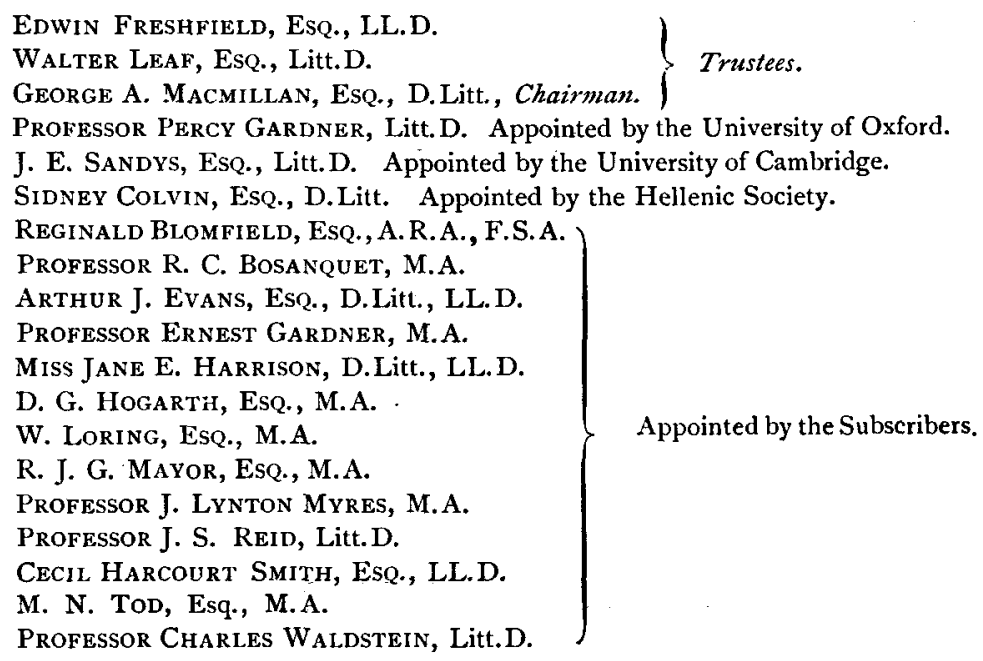

Appointed by the Subscribers.

V. W. Yorke, EsQ., M.A., Hon. Treasurer, The Farringdon Works, Shoe Lane, E.C. John ff. Baker-Penoyre, Esq., M.A., Secretary, 22, Albemarle Street, W.

\section{DIRECTOR, 1907-1908.}

R. M. Dawkins, Esq., M.A., Emmanuel College, Cambridge.

Assistant Director.-F. W. Hasluck, EsQ., M.A., Fellow of King's College, Cambridge. 


\section{TABLE OF CONTENTS.}

I. LACONIA :-

I.-Excavations at Sparta, r908. (Plates I.-VI.)

R. M. Dawkins. $\S$ r.-The Season's Work Page $" \quad$ " $"$ 2.-The Sanctuary of Artemis Orthia. (Plates I., II.) • • • • • • • • 4

J. P. Droop. $\quad \S 3$. -The Pottery. (Plates III., IV.) • • . 30

J. Farrell. $\quad \S 4$ - The Archaic Terracottas from the Sanctuai $;$ of Orthia . . . . . . . . 48

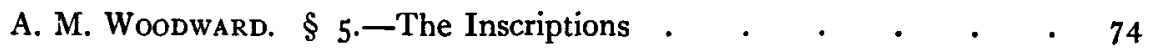

G. Dickins. $\quad \S 6 .-$ The Hieron of Athena Chalkioikos $\quad$. $\quad \mathbf{I 4 2}^{2}$

A. J. B. WACE. $\quad \S 7$ - - A Third-Century Marble Head . . . 147

" $\quad$ \$ 8.-A Hoard of Hellenistic Coins. (Plates V., VI.) 149

II.-TOPOGRAPHY.

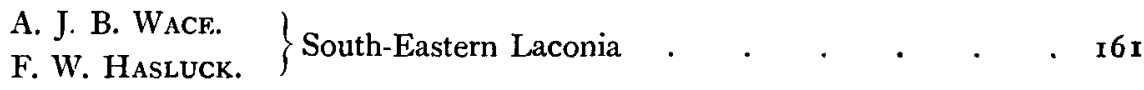

2. D. G. HogdRTh. Hierapolis Syriae . . . . . . $\quad$ I83

$\left.\begin{array}{l}\text { 3. A. J. B. Wace. } \\ \text { J. P. Droop. } \\ \text { M. S. Thompson. }\end{array}\right\}$ Excavations at Zerélia, Thessaly $. \quad . \quad . \quad$. $\quad$ I97

W. Vollgraff. Notes on the Topography of Phthiotis $\quad$ - $\quad 224$ 
4. R. M. Burrows. J Excavations at Rhitsóna in Boeotia. (Plates VII.-

PAGE

P. N. URE

5. M. M. Vassits.

South-Eastern Elements in the Pre-historic

Civilization of Servia - 319

6. D. Mackenzie.

Cretan Palaces and the Aegean Civilization. IV. 343

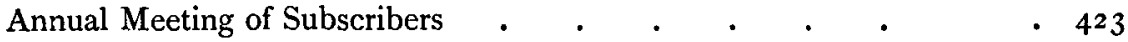

Income and Expenditure, 1907-1908 . . , . . . . $43^{8}$

Donations and Subscriptions, 1907-1908 . . . . . . 440

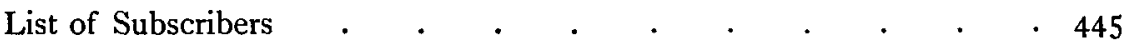

List of Directors, Honorary Students, Students, and Associates . . $45^{1}$

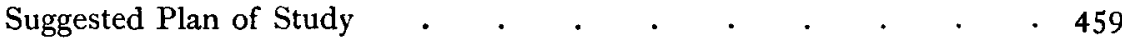

Rules and Regulations of the British School at Athens . . . 460

Index $. \quad . \quad . \quad . \quad . \quad . \quad . \quad . \quad . \quad . \quad . \quad .464$ 


\section{LIST OF PLATES.}

I. Sparta. Plan of Sanctuary of Artemis Orthia.

II. Sparta. Sectional Drawings of Sanctuary of Artemis Orthia.

III. Sparta. Kylix of Laconian III. Style.

IV. Sparta. Kylix of Laconian III. Style. Detail of Ornament and Shape.

V. Sparta. Hoard of Hellenistic Coins.

VI. Sparta. Hoard of Hellenistic Coins.

VII. Rhitsóna. Terracotta Statuettes from Graves 3 I (A) and 18 (B).

VIII. Rhitsóna. Boeotian Geometric Vases from Graves i 8 (A) and 26 (B)

IX. Rhitsóna. Vases from Graves 49 and $5 \mathrm{I}$.

X. Rhitsóna. Vases from Grave 50.

XI. Rhitsóna. Vases from Graves 26 and $3 \mathrm{I}$.

XII. Rhitsóna. Terracotta Statuettes, etc. from Graves 26 and $3 \mathbf{I}$.

XIII. Rhitsóna. Vases from Graves 18 and 22.

XIV. Rhitsóna. Red-Figure Skyphos from Grave 22.

XV. Rhitsóna. Vases from Graves $26,3 \mathrm{I}, 49$, and $5 \mathrm{I}$. 


\section{LIST OF ILLUSTRATIONS IN THE TEXT.}

LACONIA :-

$$
\text { I.-Excavations at Sparta, } 1908 .
$$

\$ 2.-The Sanctuary of Artemis Orthia.

. $\cdot 7$

Fig. 2. Houses outside the Wall of the Archaic Hieron. . . $\quad$. 8

Fig. 3. Fretwork Carvings in Bone . . . . . . . 10

Fig. 4. Lead Figurines and Pottery of about 400 B.c. . . . . . Ix

Fig. 5. View of the Sixth-century Temple and the Remains of the Primitive Temple . . . . . . . . . I7

Fig. 6. The Primitive Temple with the Edge of the Cobble-pavement, and the South Wall of the Sixth-century Temple . . 18

Fig. 7. View of the Interior of the Primitive Temple . . . . . . 19

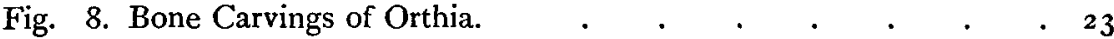

Fig. 9. Lead Figurines . . . . . . . . . . . . . 24

Fig. 10. Carvings in Soft Limestone . . . . . . . . 25

§ 3.-The PotTery.

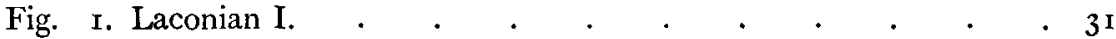

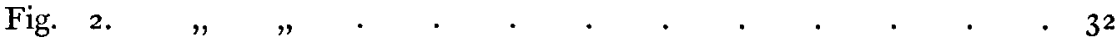

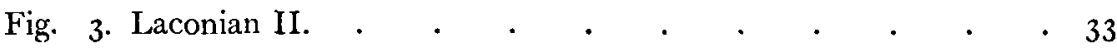

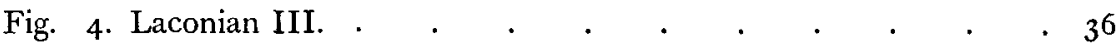

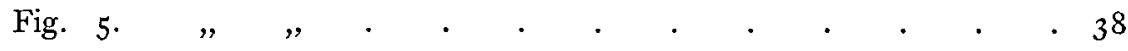

Fig. 6. $", \quad$. . . . . . . . . . . 39

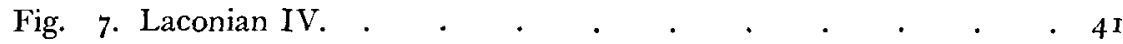

Fig. 8. Laconian V. . . . . . . . . . . 42 


\section{LACONIA (continued):-}

Fig. 9. Laconian VI. PAGE

Fig. Io. Stems of Kylikes of Laconian II. and Laconian V. . . $\quad$ - 45

\$ 4.-Archaic Terracottas from the Sanctuary of Orthia.

Fig. I. Small Hand-made Figures . . . . . . . . . 50

Fig. 2. Hand-made and Moulded Figures . . . . . $\quad$ - $\quad 53$

Fig. 3. " " " " . . . . . . . . 56

Fig. 4. Moulded Protomai and Standing Female Figures . . . 59

Fig. 5. Terracotta Heads . . . . . . . . . 6I

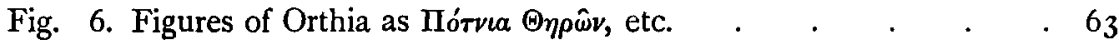

Fig. 7. Nude Male and Female Figures . . . . . . . . 66

Fig. 8. Miniature Masks . . . . . . . . . . $\quad 7^{2}$

§ 5.-INSCRIPTIONS.

Fig. 1. White Marble Stele (No. 70) . . . . . . . $\quad 7^{8}$

Fig. 2. Grey ", „ (No.73) . . . . . . . . 8 $\mathrm{r}$

Fig. 3. " " , $"($ No. 94) . . . . . . . . . 92

Fig. 4. Rosso Antico Stele (No. 60*) . . . . . . . . . 100

Fig. 5. Marble Bench (No. I) . . . . . . . . . . . IO4

§ 6.-The Hieron of Athena Chalkioikos.

Fig. I. Limestone Stele . . . . . . . . . . $\quad$. 144

Fig. 2. Bronze Statuette of Armed Aphrodite . . . . . 145

§ 7.-A Third-Century Marble Head.

Fig. I. Marble Head of a Satyr . . . . . . . . . . 147

II.-TOPOGRAPHY.

SOUTH-EASTERN LACONIA.

Text Plate. Laconia : Sketch Map of S.-E. District . . To face I6I

Fig. I. Sculptures at Neapolis . . . . . . . . . I70

Fig. 2. Cape Malea : S. Irene . . . . . . . . . . $\quad$ I73

Fig. 3. Epidaurus Limera : Plan of the Ruins . . . . . . I80

Fig. 4. " , $\quad$ Southern Wall . . . . . . I8I

Fig. 5. , , " Masonry of Tower . . . . . . I82 
Hierapolis Syriae:-

Fig. I. The Sacred Lake at Hierapolis Syriae (Mumbij) . . . 188

Fig. 2. Statue of a Recumbent Lion . . . . . . . . . I88

Fig. 3. Terracottas representing the Dea Syria . . . . . . I 90

Excavations at Zerélia, Thessaly:-

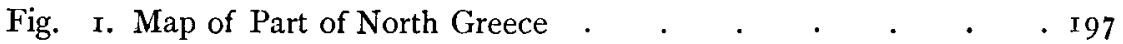

Fig. 2. Zerélia from the South . . . . . . . . . . 198

Fig. 3. " Plan and Section of Mound . . . . . . 200

Fig. 4. Diagram to explain Stratification . . . . . . $20 \mathbf{I}$

Fig. 5. Building in Second Settlement . . . . . . . 202

Fig. 6. Pottery with Red Designs on White Ground . . . . 203

Fig. 7. " " " " " " " . . . . 204

Fig. 8. Shapes of Pottery . . . . . . . . . . 205

Fig. 9. Unpainted Pottery from the Later Settlements . . . . 207

Fig. 10. Unpainted Vases from the Seventh Settlement . . . . 208

Fig. I I. Pottery with White Paint on Red Surface . . . . . . 209

Fig. I 2. Pottery with Black and Orange-red Designs . . . . 2 ro

Fig. I3. Wheel-made Pottery from the Eighth Settlement . . . 2 I 2

Fig. 14. Tombs B, C, D . . . . . . . . . 214

Fig. I5. Cist Tombs $(\mathrm{F}$ and $\mathrm{H})$. . . . . . . . . . $2 \mathrm{I} 4$

Fig. r6. Pithos from Tomb B . . . . . . . . . 215

Fig. 7 7. Terracotta Statuettes. . . . . . . . . 217

Fig. I8. Male Terracotta Statuette . . . . . . . . 218

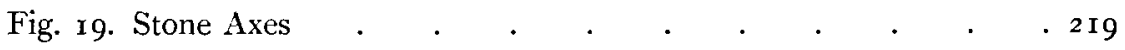

\section{Excavations at Rhitsóna, in Boeotia :-}

Fig. I. Rhitsóna: Grave Area Excavated 1907-8. . . . . . 230

Fig. 2. Euripus and Chalcis from Anephorites . . . . . . 233

Fig. 3. Anephorites from Euripus . . . . . . . . . 233

Fig. 4. Rhitsóna from Anephorites . . . . . . . . 233

Fig. 5. Junction of Chalcis and Vathy Roads . . . . . . 233

Figs. 6, 7. Nails from Graves 49 and 50. . . . . . . . 243.

Fig. 8. Grave 18 : Vases in Position . . . . . . . 248 
Excavations at Rhitsóna, in Boeotia (continued) :-

Fig. 9. Grave 50: No. 28 .

Fig. го. " $"$ No. 258 . . . . . . . . . . . . . $\quad .259$

Fig. II. " " No. 282 . . . . . . . . . . 262

Fig. I 2. Inscriptions on Vases from Graves 18, 26, 31, 49 . . . . $\quad 263$

Fig. I3. Grave 5I : No. 49 . . . . . . . . . . ${ }_{267}$

Fig. 14. " " Design on No. 231 . . . . . . . . . . . 269

Fig. 15. Grave 31 : Nos. 131, 151, 152, 153 . . . . . . 274

Fig. 16. Grave $26:$ Nos. 242, 243 . . . . . . . . . . . 286

Fig. 17. Grave 18 : Designs on No. 83, $a$ and $b$. . . . . . . 291

Fig. 18. " " No. I33. Signed by Teisias . . . . . : 293

Fig. x9. Red-Figure Kylikes in the British Museum, signed by Hermaios 294

Fig. 20. Cook Figurine (Museum of Fine Arts, Boston) . . . . 296

Fig. 21. Grave 18: No. 267 . . . . . . . . . . . . . 296

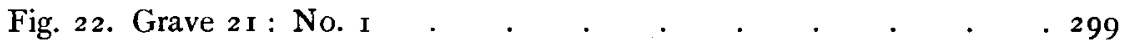

Fig. 23. Grave 22 : Inscription on No. 8 . . . . . . . . . 301

South-Eastern Elements in the Pre-historic Civilization of Servia :-

Fig. I. Two Views of Male Figure . . . . . . . . . . 321

Fig. 2. Statuette of Earliest Type . . . . . . . . . . . $\quad .323$

Fig. 3. Back of Head of Statuette of Developed Type . . . . . . 323

Fig. 4. Statuette of Decadent Type . . . . . . . . . 324

Fig. 5. Bone Statuette . . . . . . . . . . . . . $\quad . \quad 327$

Fig. 6. Statuette of Kourotrophos . . . . . . . . . . $\quad \cdot 328$

Fig. 7. Bicephalous Statuette . . . . . . . . . $\quad .328$

Fig. 8. Types of Foot of Bowls . . . . . . . . . . . . $33 \mathbf{I}$

Fig. 9. Vase Sherds with Impressed Designs . . . . . 333

Fig. Io. " " , Painted " . . . . . . . 334

Fig. 1 I. Bichrome Matt-painting on Three-Legged Altar . $\quad$. $\quad .335$

Figs. 12, 13. Vase Fragments shewing Designs Derived from Nature . 337

Fig. $14(a, b)$. Vase Fragments with Human Figures in Relief . $\quad . \quad 33^{8}$

Cretan Palaces and the Aegean Civilization IV.:-

Fig. I. Pyxis from Melos . . . . . . . . . . . . 359

Fig. 2. Neolithic House at Magasá in East Crete . . . . . . 36 
Cretan Palaces and the Aegean Civilization IV. (continued).-

Fig. 3. Prototype Rectangular House . . . . . . . . ${ }_{363}^{\text {PAGR }}$

Fig. 4. Development of $i$ ibid. . . . . . . . . . . . $\cdot 3^{63}$

Fig. 5. Early Minoan Ossuary at Kastrí . . . . . . ${ }_{3}^{363}$

Figs. 6, 7. Developments of Prototype House . $\quad . \quad \cdot \quad \cdot \quad \cdot 363$

Fig. 8. Plan of House of Period II. at Phylakopi . . . . . . 370

Figs. 9, 10, I I, I2, I3. Neolithic Houses at Dimini and Sesklo · $\quad 375$

Fig. 14. Central-Hearth Hut with Doorway at End of Wall . . . $3^{89}$

Fig. 1 5. Development of Porch in ibid. . . . . . . . . . . 389

Fig. 16. Plan of House of Period II. at Phylakopi . . . . . . 390

Figs. 17, 18, 19. Plans shewing Development of the Nordic House . . 402

Fig. 20. The Elliptical House at Chamaizi . . . . . . 402

Fig. 2 I. Diagram of Rectangular Model serving as Basis of the Elliptical

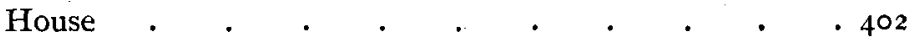

